\title{
PENGEMBANGAN DESA WISATA DI DESA BONGKASA KECAMATAN ABIANSEMAL KABUPATEN BADUNG PROVINSI BALI
}

\author{
I.G.A.O. Mahagangga ${ }^{1}$, M. Sukana ${ }^{2}$, I.B. Suryawan ${ }^{3}$ dan I.P. Anom
}

\begin{abstract}
ABSTRAK
Permasalahan utama adalah upaya awal memulai pengembangan desa wisata di desa Bongkasa. Faktanya wisatawan sudah banyak berkunjung ke desa yang berbatasan langsung dengan Ubud (Gianyar) ini. Tujuan pengabdian adalah untuk memberikan pemahaman tentang potensi pariwisata yang dimiliki dan memberikan suatu grand design perencanaan kepariwisataan dalam upaya pengembangan desa Bongkasa sebagai desa wisata. Lingkup pengabdian adalah analisis potensi wisata dan perencanaan berbasis kepada potensi serta kondisi eksisting. Metode yang digunakan adalah penyuluhan dan FGD. Di awali survei awal, penelitian lapangan dan studi pustaka. Temuan di lapangan tersebut disinergikan dengan aspirasi warga masyarakat lokal dan dianalisis secara kualitatif menggunakan konsep dan teori dalam ilmu pariwisata. Terungkap bahwa desa Bongkasa memiliki potensi alam, potensi budaya dan potensi buatan yang sangat layak untuk pengembangan desa wisata. Diperlukan perencanaan secara makro sebagai grand design yang disebut model kerangka implementasi kebijakan pengembangan desa Bongkasa sebagai desa wisata.
\end{abstract}

Kata Kunci : Pengembangan, Perencanaan, Model, Grand Design, Desa Wisata,

\begin{abstract}
The main problem is how to start the development of tourist village in Bongkasa village. In fact, the location of this village near Ubud (Gianyar) that many tourists visited everyday. The purpose of are to provide an understanding of the potential of tourism owned and provide tourism planning as grand design to develop the village of Bongkasa as a tourist village. The scope are potential tourism analysis and tourism planning. Tourism planning based on the potential and existing conditions. The method used are counseling and FGD. Starting from the initial survey, field research and literature study. The results are synergized with the aspirations of local society and analyzed qualitatively from science of tourism perspective. Revealed that the village of Bongkasa very feasible for the development of tourist villages with potential of nature, cultural potential and artificial potential. Bongkasa as a tourist village need macro planning as a grand design called framework implementation policy development model.
\end{abstract}

Keywords: Development, Planning, Model, Grand Design, Village Tourism

\footnotetext{
${ }^{1}$ Prodi S1 Destinasi Pariwisata, Fak. Pariwisata, Universitas Udayana, Email: okamahagangga@unud.ac.id

${ }^{2}$ Prodi 1 Destinasi Pariwisata, Fak. Pariwisata, Universitas Udayana, Email: sukana.made@gmail.com

${ }^{3}$ Prodi S1 Destinasi Pariwisata, Fak. Pariwisata, Universitas Udayana, Email: inigusmail@gmail.com

${ }^{4}$ Prodi S1 Destinasi Pariwisata, Fak. Pariwisata, Universitas Udayana, Email: putuanom@yahoo.com
} 


\section{PENDAhUluan}

Desa Bongkasa yang merupakan salah satu Desa dari 18 Desa yang ada di Kecamatan Abiansemal, Kabupaten Badung Provinsi Bali yang terletak 3 Km dari Ibu kota Kecamatan Abiansemal dan 23 $\mathrm{Km}$ dari pusat kota Denpasar. Letaknya strategis bersebelahan dengan Ubud kabupaten Gianyar, yang hanya dipisahkan oleh sungai Ayung. Luas tanah yang ada di Desa Bongkasa adalah 4.560 $\mathrm{Km} 2$ dengan ketinggian antara $300 \mathrm{~s} / \mathrm{d} .500 \mathrm{M}$ dari permukaan laut, tergolong dataran rendah , dengan curah hujan $2000-3000 \mathrm{MM} /$ Tahun, dengan suhu udara $26 \mathrm{C}$, pemanfaatan tanah dapat dibedakan menjadi tanah kering untuk permukiman dan tegalan / ladang dan tanah basah untuk persawahan. Pemanfaatan lahan di Desa Bongkasa antara lain lahan sawah : 314,18 Ha, lahan kering/tegalan : 71,7 Ha, ahan Perumahan : 43,34 Ha dan lahan fasilitas Umum : 8,84 Ha. Secara umum desa Bongkasa dikelilingi oleh Daerah Aliran Sungai atau DAS mencapai hampir $80 \%$ wilayahnya.

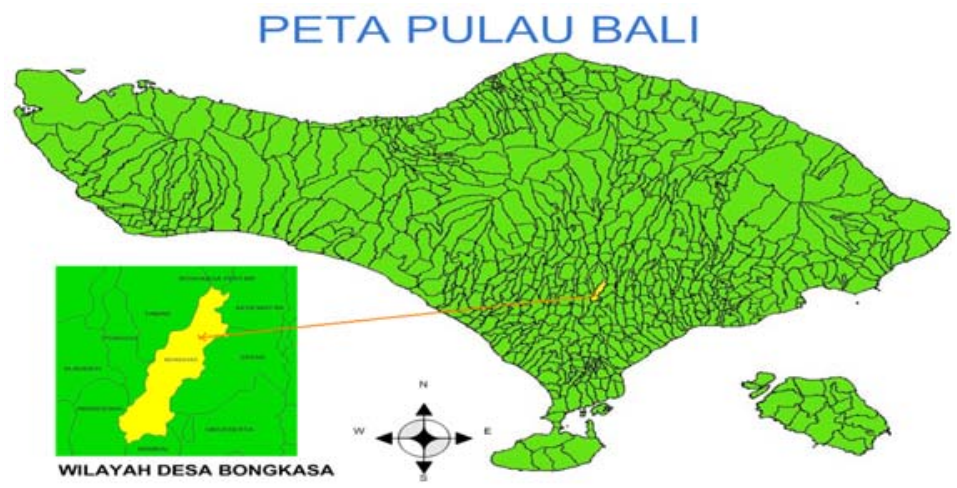

Gambar 1. Letak Desa Bongkasa

Pembagian wilayah desa dalam ruang lingkup penyelenggaraan Pemerintah Desa, Desa Bongkasa terbagi atas 10 Banjar Dinas.Banjar dinas dipimpin langsung oleh Kelian Banjar Dinas sebagai ujung tombak penyelenggara Pemerintah Desa. Adapun Banjar Dinas yang ada diwilayah Desa Bongkasa yaitu Banjar Kedewatan, Banjar Tanggayuda, Banjar Sayan Agung, Banjar Sayan Tua, Banjar Pengembungan Sari, Banjar Teguan, Banjar Pengembungan, Banjar Kambang, Banjar Kutaraga dan Banjar Tohpati. Secara adat desa Bongkasa terdiri dua desa adat yaitu desa adat Bongkasa dan desa adat Kutaraga. Desa adat Bongkasa terdiri sepuluh banjar adat yaitu banjar adat Karang Dalem 1, banjar adat Kedewatan, banjar adat, Tanggayuda, banjar adat Sayan Agung, banjar adat Sayan Tua, banjar adat Pengembungan, banjar adat Pengembungan Sari, banjar adat teguan, dan banjar adat Kambang. Desa adat Kutaraga terdiri dari dua banjar adat yaitu banjar adat Kutaraga dan banjar adat Tohpati.

\section{METODE PELAKSANAAN}

Kegiatan pengabdian dilakukan dengan teknik penyuluhan sambil menyelipkan teknik Focus Group Discussion (FGD). FGD adalah metode pemberdayaan masyarakat dengan mengedepankan potensi yang dimiliki masyarakat lokal tersebut untuk mengembangkan diri dengan bantuan dari pihak luar sebagai fasilitator (Mikkelsen, 1999: 65). FGD adalah teknik pengumpulan data berdasarkan hasil diskusi yang terarah dan terpusat pada suatu permasalahan tertentu (Bungin, 2003 :177). 
Sebelum pelaksanaan pengabdian (pengabdian dilaksanakan hari Minggu, 15-Otober-2017), tim pengabdian berkesmepatan melakukan survei awal, penelitian lapangan dan studi pustaka. Pendekatan dilakukan kepada Kepala Desa (Perbekel) desa Bongkasa Ketut Luki (mantan Anggota DPRD Badung), Ketua Badan Permusyawaratan Desa (BPD) Bongkasa I Wayan Astika yang juga mantan anggota DPRD Badung dan Ketua Kelompok Sadar Wisata (Pokdarwis) desa Bongkasa Wayan Arta (Kaprodi Manajemen Perhotelan di STIE Tri Atma Mulya / Mapindo Bali) dan dilakukan pula kepada tokoh-tokoh masyarakat.

\section{HASIL DAN PEMBAHASAN}

Kondisi eksisting menunjukkan desa Bongkasa setiap harinya sudah padat dikunjung wisatawan mancangera (500-600 wisman per hari). Namun belum dapat diakomodir oleh Pokdarwis maupun pemerintah desa karena sudah di-handle oleh investor dan perorang yang mengelola rafting, tubes, swing, agro wisata dan paket-paket wisata seperti rural traditional farmer, traditional cooking class, cycling dan jogging.

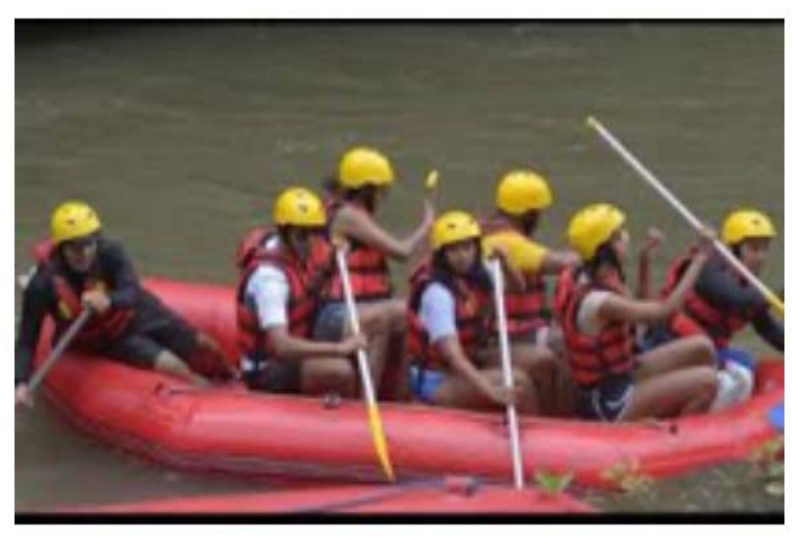

Gambar 2. Mantan Presiden USA Barack Obama dan keluarga rafting di sungai Ayung

Terlepas dari investor yang sudah membayarkan pajak dan retribusi ke pemerintah dan pemerintah desa Bongkasa sudah mendapatkannya, perlu dipikirkan bagaimana memulai pengelolaan desa wisata. Diperlulan framework atau perencanaan awal yang mampu mengakomodir seluruh potensi yang ada dengan melibatkan masyarakat secara aktif sebagai bagian dari pariwisata berbasis masyarakat. Disampaikan oleh Tim Pengabdian bahwa desa Bongkasa memiliki ragam keunikan mulai dari potensi alam, potensi budaya dan potensi buatan. Pada dasarnya para peserta yang terdiri dari aparatur pemerintah desa Bongkasa, Pokdarwis, Karang Taruna, PKK dan komponen desa lainnya menyadari telah memiliki potensi tersebut. Tetapi belum dapat dipetakan secara terstruktur dan belum diyakini akan mampu menarik perhatian wisatawan.

Ada pun potensi alam yang dimiliki di desa Bongkasa adalah sungai Ayung-sungai Adeng (termasuk mata air dan banyak pangkung, telabah yang alami), campuhan, pancoran (5 pancoran), tebing, tegal linggah, aneka buah lokal (durian, mangga, wani,juwet, sentul, kepundung, rambutan), kopi, jaka (palm wayne),kelapa, aneka tanaman bunga (soka Bali, kamboja, seroja, nusa indah, pandan harum), aneka satwa liar (bangau, perkutut, burung hantu, sikep,landak, biawak, semal, luwak, jangkrik, ular), aneka hewan peliharaan (anjing, kucing, ayam jago), areal persawahan (Julia Robert pernah shooting disini) dan areal perkebunan. 


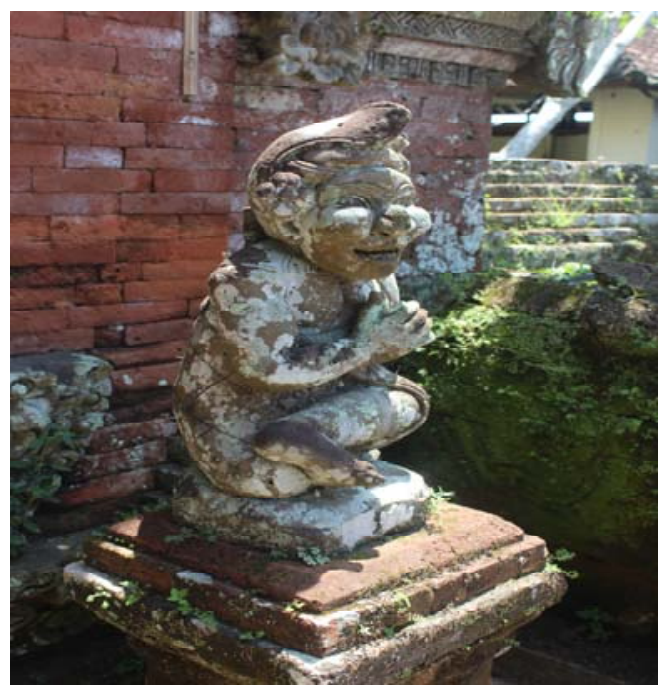

Gambar 3. Salah Satu Arca di Pura Dalem Gede Bongkasa

Potensi Budaya di desa Bongkasa adalah historis (Legenda Ki Dalang Tangsub), Puri Banyuning Bongkasa (arsitektur), Geria Gede Bongkasa (Dalang Bongkasa), Geria Agung Bongkasa (Sesepuh Sri Empu di Bali), Pura (terdapat puluhan pura), Tapakan Ratu Betara (terdapat belasan Tapakan dalam ragam perwujudan), tradisi ngunya, mepeed, meprani, ngayah, sekeha-sekeha (subak, seni, calon arang, angklung, topeng, teruna-teruni), banjar adat (padat aktifitas sosio-religius), pecalang, keris, Bapang, seni lukis, pande besi, yoga (terdapat praktisi yoga bergelar prabu), dan kuliner (sate lemo, sate nyuh, lawar, be tutu, jukut nangka, jukut ares, jaja gina, jaja uli, jaja sirat, lodek).

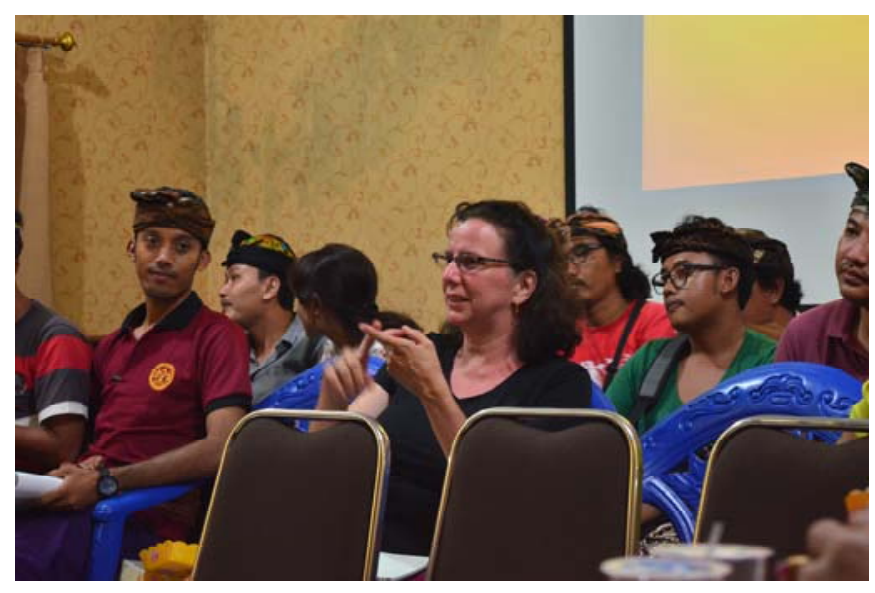

Gambar 4. Salah satu peserta asal Amerika Serikat aktif bertanya

Potensi Buatan di desa Bongkasa adalah water sport, jogging track, cycling track, ATF track, motorcross track, agro wisata organik, homestay (baru terdapat 3 homestay), restoran, water spirit (melukad), herbal-healing, spiritual yoga, spot-spot foto, production house, sanggar seni tari tradisional-kontemporer, wayang class, cooking class, galeri, art shop, stage pertunjukan, museum, guide lokal, revitalisasi pasar tradisional, klinik kesehatan, jaringan telekomunikasi, ATM, money changer, pengelolaan sampah, tag line di pintu masuk desa, tempat sampah, lampu penerangan, taman yang berisikan tanaman lokal (jaka, kelapa, kamboja, pucuk rejuna, teratai dipadukan dengan pancuran air dan patung Ki Dalang Tangsub bersama Raja Mengwi sebagai ikon cikal 
bakal desa Bongkasa), peta spot-spot wisata, jaringan transportasi lokal (terdapat grup VW lokal), toilet umum, lahan parkir, senderan sungai-hutan penyangga, telajakan rumah untuktanaman bunga lokal, saluran air perumahan, rambu-rambu petunjuk daya tarik wisata dan pos tiket, festival budaya, Tourism Information Centre, calendar event, dan Integration Management Tourism (IMT) desa wisata Bongkasa dengan menunjuk Pokdarwis atau Badan Usaha Milik Desa (BUMDES) sebagai leader-nya.

Berdasarkan hasil kajian tim pengabdian berbasis kondisi eksisting dan potensi-potensi yang dimiliki desa Bongkasa maka disampaikan model grand design pengembangan desa Bongkasa sebagai desa wisata. Model ini diharapkan dapat menjadi blue print pengembangan desa Bongkasa sebagai desa wisata kedepannya.

Tabel 3.1 Model Grand Design Pengembangan Desa Bongkasa sebagai DesaWisata

\begin{tabular}{|c|c|c|}
\hline No. & Aspek Perencanaan & Implementasi \\
\hline 1. & $\begin{array}{lr}\text { Penentuan } & \text { tujuan } \\
\text { pembangunan } & \text { desa } \\
\text { wisata } & \end{array}$ & $\begin{array}{l}\text { a. Cara pandang yang sama tentang desa wisata di } \\
\text { tingkat masyarakat lokal (arahkan kepada } \\
\text { alternative tourism bukan mass tourism, sehingga } \\
\text { tingkat partisipasi masyarakat harus tinggi dan } \\
\text { merata) } \\
\text { b. Menentukan tujuan pengembangan (pembangunan } \\
\text { sektor pariwisata bersinergi dengan sektor lain } \\
\text { untuk kesejahterahaan masyarakat) } \\
\text { c. Pertimbangan faktor sosial budaya, aspek ekonomi } \\
\text { dan lingkungan (apa yang boleh dan dilarang, } \\
\text { regulasi, hukum adat-perarem, serta kebijakan) } \\
\text { d. Merancang area pembangunan dan pengembangan } \\
\text { secara bertahap, identifikasi kepentingan secara } \\
\text { individual dan kolektif dari masyarakat lokal } \\
\text { untuk dapat diakomodasikan dan meminimalkan } \\
\text { terjadinya konflik kepentingan (pemerataan) } \\
\text { e. Kesiapan masyarakat lokal menerima sektor } \\
\text { pariwisata bersinergi dengan sektor pertanian atau } \\
\text { sektor lainnya (dimulai dari satu elemen atau satu } \\
\text { lokasi, sebagai pilot project dengan catatan } \\
\text { seluruh masyarakat turut membantu meskipun } \\
\text { tidak termasuk dalam pilot project area secara } \\
\text { langsung maupun tidak langsung). } \\
\text { f. Sosialisasi secara berkelanjutan (mulai dari sapta } \\
\text { pesona, kesadaran wisata, hospitality, dan prospek } \\
\text { desa wisata }\end{array}$ \\
\hline 2. & Inventarisasi & $\begin{array}{l}\text { a. Survai dan analisis potensi wisata yang dimiliki, } \\
\text { karakteristik kawasan pembangunan dan } \\
\text { pengembangan termasuk, ekonomi, sumber daya, } \\
\text { pola penguasaan dan pemilikan tanah, termasuk } \\
\text { tanah desa dan tanah adat. } \\
\text { b. Penelitian mendalam sejarah, budaya dan } \\
\text { kehidupan eksisting masyarakat. } \\
\text { c. Kombinasikan survai dan penelitian mendalam } \\
\text { untuk menetapkan produk, atraksi, dan aktivitas } \\
\text { pariwisata yang potensial untuk dikembangkan. } \\
\text { d. Evaluasi aksesibilitas, dan kondisi infrastruktur }\end{array}$ \\
\hline
\end{tabular}

VOLUME 17 NOMOR 1, JANUARI 2018 | 181 


\begin{tabular}{|c|c|c|}
\hline & & $\begin{array}{l}\text { pendukung dan kemungkinan pengembangannya } \\
\text { di masa depan sebagai relasi potensi buatan. } \\
\text { e. Review blue print program pengembangan desa } \\
\text { wisata dari tingkat pemerintah pusat, pemerintah } \\
\text { provinsi, hingga ke tingkat pemerintah kabupaten } \\
\text { (jangka pendek maupun jangka panjang) }\end{array}$ \\
\hline 3. & $\begin{array}{ll}\text { Infrastruktur } & \text { dan } \\
\text { Fasilitas } & \end{array}$ & $\begin{array}{l}\text { a. Penyediaan infrastruktur dan fasilitas pendukung } \\
\text { pengembangan pariwisata (relasi dengan potensi } \\
\text { buatan) } \\
\text { b. Mendorong partisipasi masyarakat dengan } \\
\text { meyakinkan bahwa desa wisata dapat bersinergi } \\
\text { dengan sektor pertanian atau sektor lainnya secara } \\
\text { berkelanjutan (core pariwisata di Bongkasa } \\
\text { tampak sangat dekat dengan alam dan budaya). }\end{array}$ \\
\hline 4. & Pasar & $\begin{array}{l}\text { a. Analisis kondisi pasar nasional dan internasional, } \\
\text { tetapkan tujuan, segmentasi khusus dan target } \\
\text { pemasaran (kondisi eksisting menunjukkan } \\
\text { wisman asala Cina melakukan rafting dan } \\
\text { domestik melakukan rafting dan outbond). } \\
\text { b. Analisis pengemasan produk dan atraksi wisata } \\
\text { yang sesuai dengan target pasar (dapat dilihat dari } \\
\text { potensi alam, potensi budaya dan potensi buatan) } \\
\text { c. Analisis akomodasi, fasilitas dan pelayanan yang } \\
\text { kelak dibutuhkan (pilihan paling tepat adalah } \\
\text { homestay, tinggal ditentukan lokasi tepatnya } \\
\text { apakah di semua banjar diperbolehkan atau } \\
\text { dibuatkan zonasi) } \\
\text { d. Pelajari target pasar dan upayakan target pasar } \\
\text { harus bisa diakses oleh IT dan transportasi } \\
\text { (Keunggulan Bongkasa dengan alam dan budaya } \\
\text { lebih cenderung cocok kepada wisatawan Eropa } \\
\text { dengan karakteristik umur 20-60 tahun). } \\
\text { e. Lakukan riset pasar bersama akademisi, sinergikan } \\
\text { dengan pihak travel agent untuk membantu } \\
\text { pemasaran dan promosi (Wisman Cina dan } \\
\text { domestik yang sudah berjalan sudah di-handle } \\
\text { oleh investor-perorangan dan travel agent dari } \\
\text { luar. Terdapat pula perorangan yang dalam skala } \\
\text { kecil rutin mendatangkan tamu Eropa di } \\
\text { homestay-nya. Upayakan kerjasama pasar dengan } \\
\text { pihak-pihak tersebut ; investor, perorangan dan } \\
\text { travel agent) }\end{array}$ \\
\hline 5. & Daya Dukung & $\begin{array}{l}\text { a. Tentukan batas ambang (carrying capacity) } \\
\text { kawasan pengembangan desa wisata melalui } \\
\text { analisis lingkungan, ekonomi dan sosial budaya } \\
\text { (mencegah terjadinya kesembrawutan, kerusakan } \\
\text { lingkungan, persaingan dan konflik sosial di } \\
\text { kemudian hari) } \\
\text { b. Tentukan batas standar yang dapat ditoleransi } \\
\text { untuk aktivitas dan kegiatan pariwisata secara } \\
\text { ekonomi termasuk batas maksimal pengunjung, } \\
\text { jumlah dan jenis kendaraan, dan kesesuaian }\end{array}$ \\
\hline
\end{tabular}




\begin{tabular}{|c|c|c|c|}
\hline & & & $\begin{array}{l}\text { dengan kawasan yang dapat didatangi } \\
\text { Implementasikan prosedur yang dapat menentukan } \\
\text { kapan kawasan pengembangan dan dalam kondisi } \\
\text { bagaimana jika terjadi suatu kerusakan termasuk } \\
\text { upaya pemulihannya (pelestarian budaya dan } \\
\text { konservasi lingkungan alam) }\end{array}$ \\
\hline 6. & Pengembangan & & 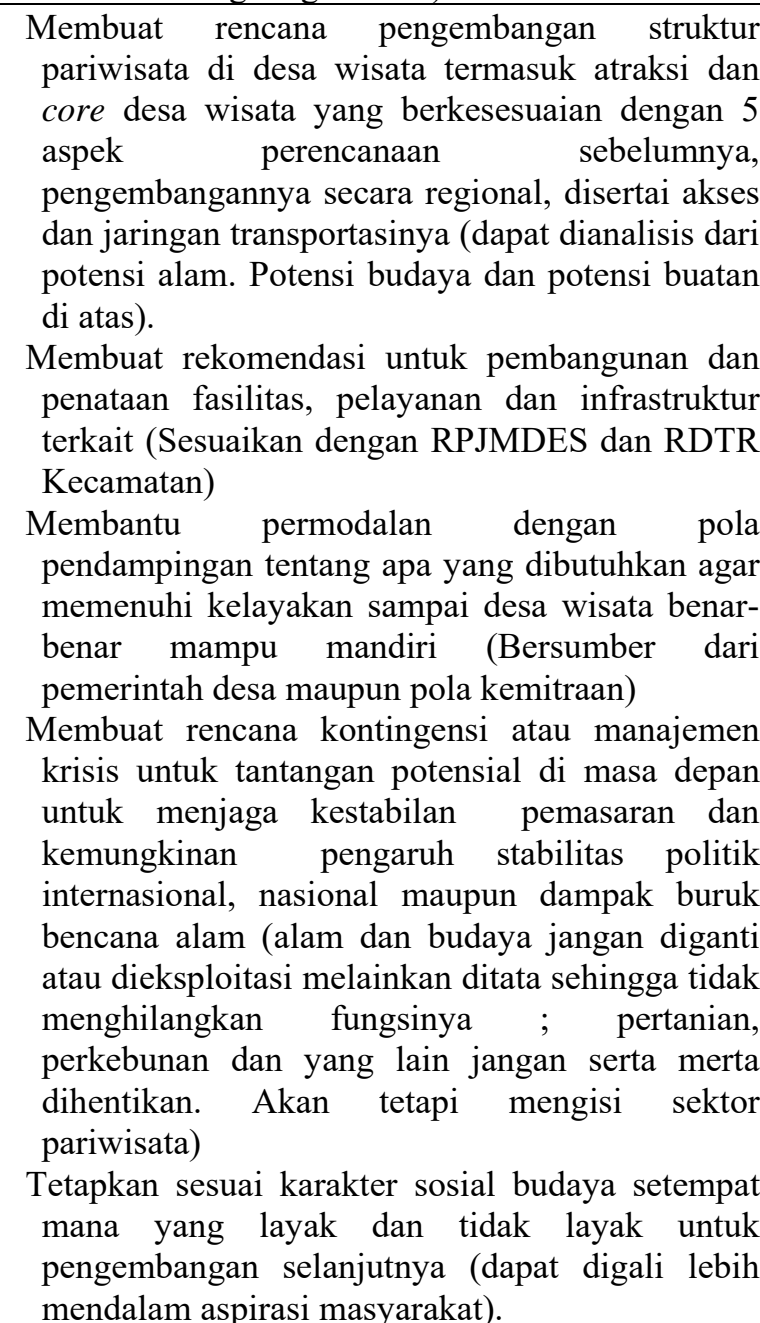 \\
\hline 7. & Ekonomi & b. & $\begin{array}{l}\text { Lakukan analisis ekonomi untuk kondisi sekarang } \\
\text { dan perkiraan masa depan dari pengembangan } \\
\text { pariwisata (dapat dilihat dari pendapatan } \\
\text { masyarakat, pola konsumsi, dan pengeluaran) } \\
\text { Membuat strategi meningkatkan keuntungan } \\
\text { ekonomi dari kegiatan pariwisata (industri kreatif } \\
\text { berdasarkan kemampuan mengakomodir potensi } \\
\text { desa) } \\
\text { Standar Operasional Procedure (SOP) yang } \\
\text { terkontrol dalam manajemen finansial sehingaa } \\
\text { desa wisata memperoleh keuntungan dan } \\
\text { wisatawan membayar kewajibannya. } \\
\text { Diperhitungkan pula sistem pembagian } \\
\text { keuntungan apabila bekerjasama dengan travel }\end{array}$ \\
\hline
\end{tabular}




\begin{tabular}{|c|c|c|c|}
\hline & & & $\begin{array}{l}\text { agent atau perorangan (Penting dipikirkan jika } \\
\text { wisatawan wajib mengeluarkan } \$ 1 \text { dalam waktu } 2 \\
\text { jam di desa Bongkasa, maka apa yang akan } \\
\text { diperoleh. Perkuat perjanjian dari aspek hukum } \\
\text { seperti MoU, kontrak dan sedapat mungkin win- } \\
\text { win solution). }\end{array}$ \\
\hline 8. & Lingkungan & b. & $\begin{array}{l}\text { Evaluasi dampak pariwisata terhadap lingkungan } \\
\text { dan tetapkan upaya pencegahan kerusakannya } \\
\text { (potret kondisi eksisting lingkungan secara } \\
\text { akademik dan lakukan secara rutin per tahun) } \\
\text { Membangun sinergi pembangunan dan } \\
\text { pengembangan pariwisata dengan usaha } \\
\text { konservasi lainnya termasuk kawasan rawan } \\
\text { longsor, zona suci, resapan air, sungai, sempadan, } \\
\text { saluran pembuangan air rumah tanggga, saluran } \\
\text { pembuagan air restoran, pengelolaan sampah, } \\
\text { pengelolaan limbah, dan bencana alam. }\end{array}$ \\
\hline 9. & Budaya & b. & $\begin{array}{l}\text { Evaluasi dampak sosial budaya pariwisata dan } \\
\text { upaya pencegahan terjadinya degradasi budaya, } \\
\text { komersialiasi budaya, komodifikasi budaya secara } \\
\text { berlebihan, penyiapan mind set masyarakat bahwa } \\
\text { wisatawan tidak hanya sekedar membawa uang, } \\
\text { perubahan mind set, life style, dan pola hidup } \\
\text { masyarakat lokal setelah pariwisata intens dengan } \\
\text { upaya revitalisasi, pelestarian dan mencegah } \\
\text { terjadinya shock culture (tegakkan aturan adat dan } \\
\text { pelestarian tradisi ; aktifitas ritual, kesenian dll.) } \\
\text { Kedepankan nilai tradisi dan adat istiadat } \\
\text { berdasarkan Tri Hita Karana dengan } \\
\text { mempertahankan modal budaya sebagai tradisi, } \\
\text { seperti aktifitas religius-spiritual, kesenian, kuliner } \\
\text { lokal, banjar adat, dan sekeha-sekeha. } \\
\text { Melakukan social mapping untuk dapat meng- } \\
\text { audit secara sosial perubahan dan pengaruh } \\
\text { masyarakat lokal karena pariwisata (melihat data } \\
\text { demografi, ibu-ibu di desa Bongkasa memiliki } \\
\text { angka cukup tinggi yang tidak bekerja formal } \\
\text { berpotensi besar untuk turut serta dalam desa } \\
\text { wisata) }\end{array}$ \\
\hline 10. & Standar Kualitas & a. & $\begin{array}{l}\text { Membuat desain untuk pengukuran standar } \\
\text { kualitas bagi fasilitas dan akomodasi untuk } \\
\text { memenuhi persyaratan pariwisata (kesepakatan } \\
\text { bersama mengacu kepada standar home stay) } \\
\text { Melakukan penilaian standar kualitas untuk } \\
\text { akomodasi dan fasilitas pendukung pariwisata } \\
\text { lainnya (teknis) } \\
\text { Memberikan pembinaan untuk mengejar standar } \\
\text { kualitas dengan pemberian rewards dalam bentuk } \\
\text { perlombaan, festival atau sejenisnya (motivasi dan } \\
\text { keberlanjutan) }\end{array}$ \\
\hline 11. & Sumber Daya Manusia & a. & $\begin{array}{l}\text { Rencanakan kebutuhan Sdm dan utamakan yang } \\
\text { sudah memiliki pengalaman di dunia pariwisata }\end{array}$ \\
\hline
\end{tabular}

184 | BULETIN UDAYANA MENGABDI 


\begin{tabular}{|c|c|c|}
\hline & & $\begin{array}{l}\text { (utamakan generasi muda yang diselaraskan } \\
\text { dengan sekeha-sekeha) } \\
\text { b. Melakukan kerjasama dengan institusi pendidikan } \\
\text { kepariwisataan untuk pembinaan dan pelatihan } \\
\text { kepariwisataan (penelitian dan pengabdian) } \\
\text { c. Penerapan pariwisata berbasis masyarakat dengan } \\
\text { mengupayakan partisipasi aktif masyarakat lokal } \\
\text { (pemerataan dan sinergitas) }\end{array}$ \\
\hline 12. & Organisasi & $\begin{array}{l}\text { a. Menetapkan struktur Pokdarwis dalam pemerintah } \\
\text { desa dan kejelasan sumber pendanaan } \\
\text { b. SOP dan job desk yang menyesuaikan dengan } \\
\text { faktor sosial budaya setempat } \\
\text { c. Membuat sistem IMT yang memudahkan } \\
\text { Pokdarwis bekerja (Potensi Buatan). } \\
\text { d. Membuat jaringan kelembagaan antara desa wisata }\end{array}$ \\
\hline 13. & Investasi & $\begin{array}{l}\text { a. Sediakan bantuan permodalan yang meningkat } \\
\text { setiap tahunnya sesuai dengan keberhasilan yang } \\
\text { diraih (Pemerintah Desa) } \\
\text { b. Memilah aset seperti tanah atau bangunan yang } \\
\text { dapat diinvestasikan untuk desa wisata } \\
\text { (Pemerintah Desa) }\end{array}$ \\
\hline 14. & $\begin{array}{l}\text { Regulasi dan } \\
\text { Pengawasan }\end{array}$ & $\begin{array}{l}\text { a. Membangun mekanisme legislasi dan regulasi } \\
\text { untuk mendorong pengembangan pariwisata } \\
\text { melalui dukungan praktisi pariwisata di Bongkasa, } \\
\text { organisasi pariwisata nasional, pemerintah } \\
\text { kabupaten, pemerintah provinsi, pemerintah pusat } \\
\text { dan sektor-sektor lainnya dalam pariwisata. } \\
\text { b. Membuat standar fasilitas, insentif investasi, dan } \\
\text { zoning (homestay, restoran, kawasan suci, } \\
\text { kawasan resapan air, kawasan ekonomi, dsb.) } \\
\text { c. Membuat prosedur penilaian dan pengawasan } \\
\text { (Pemdes bekerja sama dengan perguruan tinggi } \\
\text { pariwisata) }\end{array}$ \\
\hline 15. & $\begin{array}{l}\text { Sistem Data dan } \\
\text { Informasi }\end{array}$ & $\begin{array}{l}\text { Membangun sistem data dan informasi desa wisata } \\
\text { terintegrasi dalam suatu web site yang dapat menjadi satu } \\
\text { dengan web site Pemkab Badung yang dapat berfungsi } \\
\text { sebagai informasi pasar. }\end{array}$ \\
\hline 16. & Implementasi & $\begin{array}{l}\text { a. Identifikasi metode dan teknik untuk } \\
\text { mengimplementasikan berbagai perencanaan } \\
\text { pariwisata dan mengutamakan skala prioritas. } \\
\text { b. Kolaborasikan dengan dunia industri dan dunia } \\
\text { akademik untuk menjamin kualitas dan } \\
\text { keberlanjutan implementasi tersebut. }\end{array}$ \\
\hline
\end{tabular}

Sumber : Modifikasi Liu (1994) 


\section{Kesimpulan dan Saran}

Potensi alam, potensi budaya dan potensi buatan di desa Bongkasa layak untuk pengembangan desa wisata karena memiliki banyak keunikan. Model grand design pengembangan desa Bongkasa sebagai desa wisata dapat diterapkan dengan pemahaman bersama (Perbekel / Kepala Desa, BPD, Pokdarwis dan segenap komponen) tentang tujuan pengembangan desa wisata (berbasis kepada potensi, skala mikro, wisatawan berkualitas, partisipasi aktif masyarakat dan berkelanjutan). Visi dan Misi, dan penetapan strategi dapat direalisasikan dalam program-program kerja mengacu kepada model ini sebagai grand design atau perencanaan secara makro.

Segera disusun masterplan berdasarkan kondisi real di lapangan, faktor internal (memperhatikan perspektif historis, mapping potensi pariwisata, zonasi, kondisi eksiting, dan aspirasi masyarakat), dan faktor eksternal (kondisi pesaing-destinasi wisata serupa atau disekitar desa Bongkasa, pasar wisatawan, trend wisatawan, jejaring). Faktor internal dan faktor eksternal dianalisis secara akademis untuk perencanaan fisik (out put Detail of Design / DED) dan perencanaan non fisik (visi dan misi, tag line, kelembagaan, pola kerjasama, hubungan-hubungan sosial, produk, atraksi, paket wisata dan dampak) yang saling mendukung. Tindak lanjut masterplan disesuaikan dengan anggaran, kondisi sosial-budaya dan aspirasi masyarakat dan dapat diajukan kepada pemerintah kabupaten, pemerintah provinsi maupun pemerintah pusat.

\section{UCAPAN TERIMAKASIH}

Terima kasih kami ucapkan kepada Rektor dan Ketua LPPM Universitas Udayana, Kepala Desa, BPD, Pokdarwis, dan seluruh komponen masyarakat Bongkasa sehingga pengabdian kepada masyarakat melalui Udayana Mengabdi dapat terselenggara sesuai dengan harapan.

\section{DAFTAR PUSTAKA}

Anonim. 2012. Monografi Desa Bongkasa. Badung : Pemde Bongkasa

Anonim. 2016. Profil Desa Bongkasa. Badung : Pemdes Bongkasa

Bungin, Burhan. 2010. Metodelogi Penelitian Kualitatif. Jakarta : Kencana Prenada Media Group

Liu, Juanita C. 1994. Pacific Islands Ecotourism : A Public Policy and Planning

Guide. Hawai'i : The Pacific Business Center Program. College of Business Administrattion University of Hawai'I at Manoa Honolulu USA

Mahagangga, I Gusti Agung, I Made Bayuariwangsa, I Made Kusumanegara. 2016.

Kajian Perencanaan Desa Wisata Secara Berkelanjutan (Studi Kasus 11 Desa Wisata di Kabupaten Badung). Pengembangan Desa Wisata di Kabupaten Badung. Ed. I Putu Anom dan Ida Bagus Suryawan. Depok : Herya Media

Mikkelsen, Britha. 1999. Metode Penelitian Partisipatoris dan Upaya-Upaya

Pemberdayaan. Yayasan Obor Indonesia, Jakarta.

Suyitno. 2001. Perencanaan Wisata. Yogyakarta : Kanisius

Yoeti, Oka A. 1999. Perencanaan dan Pengembangan Pariwisata. Jakarta : PT. Pradnya Paramita 